Check for updates

Seattle

Cite this as: $B M J 2020 ; 371: m 4455$ http://dx.doi.org/10.1136/bmj.m4455 Published: 16 November 2020

\section{Covid-19: North Dakota and Belgium have let infected health staff work on wards}

\author{
Joanne Silberner
}

Authorities in Belgium and the US state of North Dakota are allowing healthcare workers with covid-19 back to work, claiming that staff shortages necessitated the move.

On 9 November the state health officer of North Dakota signed an order specifically exempting healthcare workers from a statewide requirement that people who have tested positive for SARS-CoV-2 isolate at home for 10 days. " "Health care workers are exempt from this order solely for purposes of working in a covid unit within a licensed health care facility," the order states.

The governor of North Dakota, Doug Burgum, said at a press conference that he wasn't worried about the spread of infection since the coronavirus positive staff would be caring only for patients with covid-19.

Two days later the North Dakota Nurses Association issued a statement saying it did not support the practice as a long term solution. Covid positive nurses should be able to decide for themselves whether they should be working, and employers should not pressure them, it said.

The state has been struggling with a severe second wave. The New York Times calculated that the daily number of diagnoses there has risen by $37 \%$ in the past two weeks. ${ }^{2}$ On 14 November the state reported 2270 new cases, triple the 702 on 14 October.

Belgium has also been severely affected by a second wave. It now has 63 patients per 100 ooo population in hospital with covid-19, Europe's second highest rate after the Czech Republic at 77 per 100 0oo, and more than double what it had during the spring peak. ${ }^{3}$

Belgium's public health advisory agency, Sciensano, has set up guidelines for asymptomatic coronavirus positive doctors and nurses to work. ${ }^{4}$ These say that such staff can be asked to work in "very exceptional cases" and only with patients in covid-19 units. Infected workers are to use separate entrances, changing rooms, and break areas.

Philippe Devos, head of Belgium's association of medical unions, said in an interview with Deutsche Welle that $10 \%$ of doctors and nurses at his hospital, CHC Montlegia, were at home sick because of covid-19, while in other hospitals in the country the absence rate was 25\%.4 "We don't have any solution any more," he said. "We are forced to ask them to work, if they agree.”

Alison Pittard, head of the UK Faculty of Intensive Care Medicine, said on a recent $B M J$ podcast that she was left "speechless" by the move. ${ }^{5}$ She said, "If [healthcare workers are] positive, they're not just going to come into contact with their patients. They're going to come into contact with members of the public and their own coworkers," she said. Staff shortage or not, infected healthcare workers should be treated like anyone else, she added.

1 State of North Dakota Department of Health state health officer confinement order relating to disease control measures to prevent the spread of 2019-ncov/covid-19 pursuant to North Dakota century code §23-01-05(12) order \# 2020-05.2. https://www.health.nd.gov/sites/www/files/documents/Files/MSS/coronavirus/State\%20Health\%200fficer\%200rders/202005.2_isolation_health_care_excemption.pdf.

2 North Dakota covid map and case count. New York Times. Nov 2020. https://www.nytimes.com/interactive/2020/us/north-dakota-coronaviruscases.html.

3 Europe's hospital crunch grows more dire, surpassing spring peak. 6 Nov 2020. https://www.nytimes.com/interactive/2020/11/06/world/europe/europe-covid-hospitals.html.

4 Hospitals can deploy staff with covid-19 "in very exceptional cases," Sciensano says. Brussels Times. 28 Oct 2020. https://www.brusselstimes.com/news/belgium-all-news/health/138039/hospitals-can-deploy staff-with-covid-19-in-very-exceptional-cases-sciensano-says-coronavirushospitalisations-intensive-care-unit.

5 BMJ Talk Medicine. How well did hospitals perform for their staff during covid? https://soundcloud.com/bmjpodcasts/how-well-did-hospitals-perform-for-their-staff-during-covid.

This article is made freely available for use in accordance with BMJ's website terms and conditions for the duration of the covid-19 pandemic or until otherwise determined by BMJ. You may use, download and print the article for any lawful, non-commercial purpose (including text and data mining) provided that all copyright notices and trade marks are retained. 